\title{
Discount rates and risky sexual behaviors among teenagers and young adults
}

\author{
Harrell W. Chesson · Jami S. Leichliter • \\ Gregory D. Zimet • Susan L. Rosenthal · \\ David I. Bernstein • Kenneth H. Fife
}

(C) Springer Science + Business Media, LLC 2006

\begin{abstract}
This article examines the relationship between personal discount rates and sexual behaviors in a sample of teenagers and young adults. We find that higher discount rates (an indication of less willingness to forego current consumption for future consumption) are significantly associated with a range of sexual behaviors, including ever having sex, having sex before age 16 years, and past or current pregnancy. These associations are consistent with previous studies showing a link between discounting and other, non-sexual health behaviors.
\end{abstract}

Keywords Discounting $\cdot$ Health $\cdot$ Sexually transmitted diseases $\cdot$ Risky sex $\cdot$ Young people

JEL Classification D80 - D90 · I10

Teenagers and young adults in the United States are at high risk of acquiring sexually transmitted diseases (STDs), including human immunodeficiency virus (HIV). A recent study suggests that 15-24-year-olds accounted for more than nine million new cases of STDs in

H. W. Chesson $(\bowtie) \cdot$ J. S. Leichliter

Centers for Disease Control and Prevention, Atlanta, GA

e-mail: hbc7@cdc.gov

G. D. Zimet

Department of Pediatrics, Indiana University School of Medicine, Indianapolis, IN

\section{S. L. Rosenthal}

Department of Pediatrics and Sealy Center for Vaccine Development, University of Texas Medical Branch, Galveston, TX

\section{I. Bernstein}

Department of Pediatrics and Cincinnati Children's Hospital Medical Center, University of Cincinnati College of Medicine, Cincinnati, $\mathrm{OH}$

K. H. Fife

Departments of Medicine, Microbiology \& Immunology, and Pathology, Indiana University School of Medicine, Indianapolis, IN 
2000, about half of all cases (Weinstock et al., 2004). The discounted, lifetime medical cost associated with these nine million new cases is estimated at $\$ 6.5$ billion (Chesson et al., 2004). In addition to the direct medical costs, STDs in young people impose indirect and intangible costs, such as lost wages due to STD-related illness and the costs of STD-related pain and suffering.

The costs of infection (including indirect and intangible costs) can be lifelong, particularly infection with incurable viral STDs such as HIV or herpes simplex virus type 2 (HSV-2). Because the costs of STDs can extend well into the future, an individual's perception of the cost of acquiring an STD might be influenced by that individual's discount rate. ${ }^{1}$ For example, because HIV has a long latency period, infection with HIV might be perceived as less costly to teenagers and young adults with higher discount rates than those with lower discount rates, all else equal. If so, a person's rate of time preference may influence his or her decision of whether or not to engage in risky sexual behaviors.

To our knowledge, no previous study has examined the relationship between time preference and sexual health, although economists and other social scientists provide evidence that time preference is related to health investment and health status (Fuchs, 1982; Evans and Montgomery, 1994). Several studies suggest a link between higher discount rates and risky health behaviors, such as smoking (Viscusi, 1991; Munasinghe and Sicherman, 2000; Viscusi and Hersch, 2001), reduced willingness to receive a flu vaccine (Chapman and Coups, 1999), reduced participation in cancer screening (Picone et al., 2004), heroin and cocaine abuse (Kirby and Petry, 2004), and being obese (Komlos et al., 2004). However, these associations are often weak, and studies of the role of time preference in health-related decision making have yielded mixed results (Fuchs, 1982; Chapman, 2002, 2005). The purpose of this paper is to examine whether or not annual discount rates for monetary gains are related to sexual behaviors and sexual health among teenagers and young adults. We find that higher discount rates are associated with sexual behaviors and sexual health outcomes, such as ever having sex, earlier age of sexual debut, and pregnancy.

The remainder of this paper is structured as follows: Section 1 presents a simple model of sexual behavioral decision making over time and discusses why personal discount rates may or may not be correlated with sexual behaviors. Section 2 describes the data and the methods used to assess individual discount rates. Section 3 presents results, including estimates of individual discount rates, associations between discount rates and sexual behaviors and health, and additional analyses to examine the validity of the discount rate measurement. Concluding remarks are presented in Section 4.

\section{A simple model of sexual behavioral decision making}

Simple models can illustrate why discount rates might or might not be expected to influence sexual behavioral decision making. Suppose that a person's utility in a given period $t$ is a function of sexual activity level $(S)$ in period $t$ and the costs $(C)$ of sexual activity in period $t$ and in previous periods. This utility function can be written $u_{t}\left(S_{t}, C\left(\sum_{1}^{t} S_{t}\right)\right)$ and is decreasing in $C$, such that the benefits of sexual activity in a given period can be offset (either partially or completely) by the short- and long-term consequences of past and current sexual activity, such as disease acquisition, unwanted pregnancy, and psychological distress

\footnotetext{
${ }^{1}$ Higher discount rates indicate less willingness to exchange current consumption for future consumption. In this study, for example, persons who were indifferent between receiving $\$ 400$ immediately and $\$ 500$ in one year were assumed to have a discount rate of $25 \%$.
} 
(Upchurch et al., 2004). In period $t$ the person chooses a sexual activity level to maximize the discounted utility function $U^{t} \equiv \sum_{\tau=t}^{T}\left(\frac{1}{1+\rho}\right)^{\tau-t} u_{\tau}$, where $\rho$ is the person's discount rate (O'Donoghue and Rabin, 2001). Although the costs of sexual activity in period $t$ can extend into subsequent periods, these future costs are discounted, and the decision to engage in sexual activity becomes more attractive as the discount rate increases. Thus, this simple model would suggest that sexual behaviors would be correlated with discount rates. All else equal, persons with higher discount rates would be more likely to have had sex, to have more sexual partners, to have unprotected sex, to become pregnant or to impregnate someone, or to acquire a sexually transmitted disease, than persons with lower discount rates.

This simple model, however, might overstate the role of discount rates on sexual behavioral decision making, for several reasons. For example, many people, perhaps especially teenagers and young adults, have a strong preference for immediate gratification, a preference that is not reflected in the above model. A model that allows for declining discounting over time would more realistically reflect observed decisions under intertemporal choice. ${ }^{2}$ Furthermore, decisions about sexual behavior might be made in the "heat of the moment," at which time little thought (if any) may be given to the possible future consequences of sexual activity. Recent research has suggested that people in "hot" states (in this case, sexual arousal) often fail to appreciate how much their "hot" state can influence their decision making. Similarly, people in "cold" states (in this case, not sexually aroused) may not be able to imagine or accurately predict what decisions they will make in future "hot" states. ${ }^{3}$ An imprudent focus on immediate rewards can also be explained by Read and Roelofsma (1999) and Read (2001b), who discuss "intrapersonal dilemmas" in which people make choices that are in their best interest at the time but not in the long run.

To account for an emphasis on short-term gratification, the expected utility model can be adjusted as follows: $U^{t} \equiv u_{t}+\beta \sum_{\tau=t+1}^{T}\left(\frac{1}{1+\rho}\right)^{\tau-t} u_{\tau}$, where $\beta$ is a preference for immediate gratification (O'Donoghue and Rabin, 2001). ${ }^{4}$ The preference term $(\beta)$ can range from 0 to 1 , where 0 represents a total focus on immediate gratification (all future periods are disregarded), and 1 corresponds to no additional emphasis on immediate gratification. Although this model would still predict some influence of discount rates on sexual behavior, such influence would be diminished by the preference term $(\beta)$ and would be eliminated altogether if $\beta=0$. Thus, it is possible in this simple model that decisions about sexual behavior are situation-specific and unrelated to discount rates. If, however, persons with lower discount rates are more likely to avoid situations which might lead to sexual activity (see O'Donoghue and Rabin, 2001), then discount rates might be expected to be correlated with sexual behaviors.

\section{Data description and assessment of individual discount rates}

We examined survey responses from a sample recruited from the following populations in Indianapolis and Cincinnati: clients of a public STD clinic, clients of adolescent health clinic, clients of two general medical clinics, and students at a large, public university campus. All of the sites were in urban areas with the exception of one suburban general medicine clinic. Respondents were recruited as part of a larger study examining herpes simplex virus type

\footnotetext{
${ }^{2}$ For example, see O'Donoghue and Rabin (2001), Read (2001a), Frederick et al. (2002), and Read and Roelofsma (2003).

${ }^{3}$ For discussion of decision making in "hot" and "cold" states, see Loewenstein (2005a and 2005b).

4 This model, used by O'Donoghue and Rabin (2001) and others to describe temporal decision making (including sexual behavioral decision making by youth), is based on work by Phelps and Pollak (1968).
} 
Table 1 Demographics, sexual behaviors, and health outcomes of study sample, by site of data collection

\begin{tabular}{|c|c|c|c|c|c|}
\hline & $\begin{array}{l}\text { STD } \\
\text { clinic }\end{array}$ & $\begin{array}{l}\text { General } \\
\text { clinic }\end{array}$ & $\begin{array}{l}\text { University } \\
\text { campus }\end{array}$ & $\begin{array}{l}\text { Teen } \\
\text { clinic }\end{array}$ & Total \\
\hline Sample size & 283 & 259 & 310 & 190 & 1042 \\
\hline Male $(\%)$ & 53.5 & 21.6 & 41.0 & 53.2 & 41.8 \\
\hline White $(\%)$ & 55.0 & 87.4 & 80.5 & 23.2 & 64.5 \\
\hline Age (mean) & 23.2 years & 23.2 years & 22.3 years & 17.2 years & 21.8 years \\
\hline $\begin{array}{l}\text { Ever had sexual } \\
\quad \text { intercourse }(\%)\end{array}$ & 95.4 & 94.1 & 85.8 & 84.7 & 90.2 \\
\hline $\begin{array}{l}\text { Ever had gonorrhea } \\
\text { and/or chlamydia }(\%)\end{array}$ & 35.7 & 18.1 & 4.5 & 22.3 & 19.6 \\
\hline $\begin{array}{l}\text { Had sexual intercourse } \\
\text { before age } 16(\%)\end{array}$ & 47.7 & 39.6 & 16.8 & 62.4 & 39.1 \\
\hline $\begin{array}{l}>1 \text { sex partner in previous } \\
\quad \text { six months }(\%)\end{array}$ & 51.6 & 13.3 & 16.2 & 31.5 & 27.9 \\
\hline $\begin{array}{l}\text { Had } \geq 1 \text { unprotected sex act } \\
\text { in previous } 6 \text { months }(\%)\end{array}$ & 72.3 & 74.5 & 55.3 & 40.2 & 61.9 \\
\hline $\begin{array}{l}\text { Is or was pregnant, or } \\
\text { has impregnated someone }(\%)\end{array}$ & 45.8 & 62.6 & 10.7 & 30.1 & 36.7 \\
\hline Acceptance of HSV-2 test (\%) & 90.1 & 45.6 & 66.1 & 54.2 & 65.4 \\
\hline Presence of HSV-2 antibody (\%) & 24.7 & 22.0 & 8.3 & 8.7 & 16.9 \\
\hline
\end{tabular}

Sample size $=1042$, although some measures contain missing values. All sexual behaviors and outcomes were self-reported, except for "tested positive for HSV-2" which was obtained from patients who accepted the HSV-2 test.

2 (HSV-2) antibody test acceptance and attitudinal, behavioral, and demographic factors as predictors of HSV-2 test acceptance. Details regarding the recruitment sites and sampling methods have been published elsewhere (Fife et al., 2004; Fortenberry et al., 2004; Zimet et al., 2004). The average age of the respondents was 21.8 years (range: 14-30 years) and most respondents were sexually active (Table 1).

We calculated discount rates based on responses to three hypothetical questions about the possible payoff of a prize. In the first question, each person was asked to choose between a prize of $\$ 400$ to be awarded today and a prize of $\$ 1,200$ to be awarded one year from today. In the second and third questions, the value of the future prize was reduced to $\$ 800$ and $\$ 500$, respectively (Table 2). In each question, the respondents were asked whether or not they agreed with the statement "I would prefer to win $\$ 400$ today." Possible responses ranged from strongly disagree (1) to strongly agree (5).

Because the cost of accepting the $\$ 400$ instant payoff decreased from question 1 to question 2 (and from question 2 to question 3 ), we assumed that no subject would have been less willing to accept the $\$ 400$ instant payoff when moving from question 1 to question 2 to question 3 . For example, a subject who responded "strongly agree" in question 1 would be expected to respond "strongly agree" to questions 2 and 3 . In addition, we assumed that no subject would provide a response of "neutral" in more than one of the three questions. We classified subjects who violated either or both of these two assumptions or who failed to respond to all three monetary questions as "inconsistent" $(n=257)$ and excluded them from the main analyses. ${ }^{5}$

\footnotetext{
5 In the consistency check, we distinguished between strength of preference. That is, respondents who changed from "strongly agree" to "agree" or who changed from "disagree" to "strongly disagree" from question 1 to question 2, or from question 2 to question 3, were labeled "inconsistent." The percentage of subjects responding 
Table 2 Survey questions used to measure time preference

Now we are going to ask you questions about money.

Suppose you won a prize, and you get to make a choice about winning your prize today, or waiting a year and receiving a bigger prize.

\begin{tabular}{llllll}
\hline & Strongly Disagree & Disagree & Neutral & Agree & Strongly agree \\
\hline $\begin{array}{c}\text { I would rather get } \$ 400 \text { today } \\
\text { than } \$ 1,200 \text { one year from today }\end{array}$ & $\mathrm{O}$ & $\mathrm{O}$ & $\mathrm{O}$ & $\mathrm{O}$ & $\mathrm{O}$ \\
$\begin{array}{c}\text { I would rather get } \$ 400 \text { today } \\
\text { than } \$ 800 \text { one year from today }\end{array}$ & $\mathrm{O}$ & $\mathrm{O}$ & $\mathrm{O}$ & $\mathrm{O}$ & $\mathrm{O}$ \\
$\begin{array}{c}\text { I would rather get } \$ 400 \text { today } \\
\text { than } \$ 500 \text { one year from today }\end{array}$ & $\mathrm{O}$ & $\mathrm{O}$ & $\mathrm{O}$ & $\mathrm{O}$ & $\mathrm{O}$ \\
\hline
\end{tabular}

For subjects who responded consistently $(n=1042)$, we assigned a crude estimate of their personal discount rate.

Specifically, each consistent respondent was assigned to one of seven discount rate ranges: $r<25 \%, r=25 \%, 25 \%<r<100 \%, r=100 \%, 100 \%<r<200 \%, r=$ $200 \%, r>200 \%$. In assigning the discount rate ranges, no distinction was made between a response of "strongly disagree" or "disagree", and no distinction was made between a response of "agree" or "strongly agree." 6 The discount rate range of $<25 \%$ was assigned to those who disagreed in question 3 , and the discount rate range of $>200 \%$ was assigned to those who agreed in question 1 . The discount rate range of $25 \%<r<100 \%(100 \%<r<200 \%)$ was assigned to those whose responses changed from disagree to agree from question 2 to question 3 (question 1 to question 2). The discount rates of $200 \%, 100 \%$, and $25 \%$ were assigned to those who responded "neutral" to question 1,2 , or 3 , respectively.

\section{Results}

\subsection{Individual discount rates}

Almost half of the subjects exhibited an annual discount rate $(r)$ of $100 \%$ or more (Table 3 ). That is, they required at least $\$ 800$ to be awarded in one year to forego receiving $\$ 400$ immediately. The estimated discount rate was greater than $200 \%$ for one-fifth of the respondents and was less than $25 \%$ for only $13 \%$ of the respondents.

A recent review of published estimates of discount rates (Frederick et al., 2002) included several studies reporting discount rates above $100 \%$ (and above $200 \%$ in some cases) when examining tradeoffs over time horizons of one year or less. Although our results were not inconsistent with the upper range of previous assessments of discount rates over a short time horizon, the high discount rates we observed may be attributable in part to "anchoring" to the tradeoff proposed in the first question (see Green et al., 1998 and Frederick et al., 2002). For example, the tradeoff proposed in the first question ( $\$ 400$ today versus $\$ 1,200$ in one year) implies a very high discount rate, which may have biased the responses to the

inconsistently is consistent with that observed in similar surveys such as Viscusi et al. (1991) and Chesson and Viscusi (2000). As described later, we performed additional analyses in which inconsistent responders were included.

${ }^{6}$ These distinctions of degree of disagreement or agreement were used in the consistency check, but not in establishing the discount rate ranges. 
Table 3 Summary of annual personal discount rates $(r)$ implied by responses to prize payoff questions

\begin{tabular}{lc}
\hline Implied discount rate $(r)$ & Number $(\%)$ of subjects $(N=1042)$ \\
\hline$r<25 \%$ & $134(12.9 \%)$ \\
$r=25 \%$ & $64(6.1 \%)$ \\
$25 \%<r<100 \%$ & $352(33.8 \%)$ \\
$r=100 \%$ & $112(10.7 \%)$ \\
$100 \%<r<200 \%$ & $106(10.2 \%)$ \\
$r=200 \%$ & $44(4.2 \%)$ \\
$r>200 \%$ & $230(22.1 \%)$ \\
\hline
\end{tabular}

subsequent questions towards a higher discount rate. ${ }^{7}$ Although our measure of discount rates is not well suited to gauge absolute rates of time preference, the responses to the three monetary questions do allow us to assess relative differences in time preference, at least to some degree. In the following section, we examine the association between relative discount rates and sexual behaviors.

\subsection{Associations between discount rates and sexual behavior, sexual health}

To analyze the association between discount rates and sexual behaviors, we divided the respondents into discount rate groups based on their choices to the monetary payoff questions. Although there were at least seven possible groupings of discount rates based on the responses to the three time-tradeoff questions, we collapsed the responses into four groups $(r \leq 25 \%, 25 \%<r \leq 100 \%, 100 \%<r \leq 200 \%$, and $r>200 \%$ ) such that the groups would be more comparable in size. ${ }^{8}$ We examined differences across these four groups over a range of sexual behaviors and health outcomes, including: ever having sexual intercourse, having sexual intercourse before age 16, having a history of gonorrhea and/or chlamydia infection, having more than 1 sex partner in the previous six months, having at least one unprotected sex act in the previous six months, pregnancy status, acceptance of an HSV-2 test, and presence of HSV-2 antibody. ${ }^{9}$ The pregnancy status variable was set to 1 for females with previous or current pregnancy and for males who had ever impregnated someone. With the exception of HSV-2 antibody status, all measures were self-reported.

In general, for the full sample, there were significant differences in sexual behaviors and health outcomes associated with discount rates (Table 4, Panel A). Respondents with higher discount rates were more likely to have ever had sexual intercourse, to have ever had gonorrhea or chlamydia, to have had sexual intercourse before age 16 years, to have had more than one sex partner in the previous six months, and to have been or currently be pregnant or to have impregnated someone. There was no significant association between discount rates and having at least one unprotected sex act in the previous six months, acceptance of an HSV-2 test, or presence of HSV-2 antibody. Our measure of unprotected sex, however, did not control for status of the sex partner, and might therefore not be a reliable indicator of risky sexual activity. Evidence suggests that unprotected sex is more common with lowrisk partners than with high-risk partners (Peterman et al., 2000). Unprotected sex carries

\footnotetext{
${ }^{7}$ We address this issue later by focusing solely on the responses to the first monetary tradeoff question.

${ }^{8}$ Our results are generally consistent (particularly for the full sample) when we use seven discount rate groups rather than four.

${ }^{9}$ The subjects were asked the number of times they had sex, and the number of times that a condom was used. We defined having unprotected sex at least once if the former exceeded the latter.
} 
Table 4 Sexual behaviors and health outcomes, by discount rate $(r)$

\begin{tabular}{|c|c|c|c|c|c|}
\hline $\begin{array}{l}\text { Self-reported } \\
\text { behavior/outcome }\end{array}$ & $\begin{array}{l}\text { Group 1: } \\
r \leq 25 \%\end{array}$ & $\begin{array}{l}\text { Group 2: } \\
25 \%<r \leq \\
100 \%\end{array}$ & $\begin{array}{l}\text { Group 3: } \\
100 \%<r \leq \\
200 \%\end{array}$ & $\begin{array}{l}\text { Group 4: } \\
r> \\
200 \%\end{array}$ & $p$-value* \\
\hline \multicolumn{6}{|c|}{ Panel A: Full sample } \\
\hline Ever had sexual intercourse & $\begin{array}{l}83.8 \% \\
(165 \text { of } 197)\end{array}$ & $\begin{array}{l}90.5 \% \\
(316 \text { of } 349)\end{array}$ & $\begin{array}{l}91.2 \% \\
(239 \text { of } 262)\end{array}$ & $\begin{array}{l}94.2 \% \\
(213 \text { of } 226)\end{array}$ & 0.003 \\
\hline $\begin{array}{l}\text { Ever had gonorrhea and/or } \\
\text { chlamydia }\end{array}$ & $\begin{array}{l}14.2 \% \\
(28 \text { of } 197)\end{array}$ & $\begin{array}{l}17.8 \% \\
(62 \text { of } 349)\end{array}$ & $\begin{array}{l}17.9 \% \\
(46 \text { of } 257)\end{array}$ & $\begin{array}{l}29.1 \% \\
(66 \text { of } 227)\end{array}$ & $<0.001$ \\
\hline $\begin{array}{l}\text { Had sexual intercourse before } \\
\quad \text { age } 16\end{array}$ & $\begin{array}{l}25.3 \% \\
(50 \text { of } 198)\end{array}$ & $\begin{array}{l}34.7 \% \\
(121 \text { of } 349)\end{array}$ & $\begin{array}{l}42.9 \% \\
(111 \text { of } 259)\end{array}$ & $\begin{array}{l}53.8 \% \\
(120 \text { of } 223)\end{array}$ & $<0.001$ \\
\hline $\begin{array}{l}>1 \text { sex partner in previous six } \\
\text { months }\end{array}$ & $\begin{array}{l}20.1 \% \\
(39 \text { of } 194)\end{array}$ & $\begin{array}{l}27.0 \% \\
(93 \text { of } 345)\end{array}$ & $\begin{array}{l}30.4 \% \\
(79 \text { of } 260)\end{array}$ & $\begin{array}{l}33.2 \% \\
(74 \text { of } 223)\end{array}$ & 0.019 \\
\hline $\begin{array}{l}\text { Had at least one unprotected sex } \\
\text { act in previous six months }\end{array}$ & $\begin{array}{l}60.1 \% \\
(110 \text { of } 183)\end{array}$ & $\begin{array}{l}63.8 \% \\
(215 \text { of } 337)\end{array}$ & $\begin{array}{l}56.9 \% \\
(141 \text { of } 248)\end{array}$ & $\begin{array}{l}66.2 \% \\
(141 \text { of } 213)\end{array}$ & 0.164 \\
\hline $\begin{array}{l}\text { Is or has been pregnant, or has } \\
\text { impregnated someone }\end{array}$ & $\begin{array}{l}34.5 \% \\
(67 \text { of } 194)\end{array}$ & $\begin{array}{l}27.6 \% \\
(97 \text { of } 351)\end{array}$ & $\begin{array}{l}39.8 \% \\
(102 \text { of } 256)\end{array}$ & $\begin{array}{l}48.7 \% \\
(110 \text { of } 226)\end{array}$ & $<0.001$ \\
\hline Acceptance of HSV-2 test & $\begin{array}{l}64.6 \% \\
(128 \text { of } 198)\end{array}$ & $\begin{array}{l}68.8 \% \\
(242 \text { of } 352)\end{array}$ & $\begin{array}{l}61.5 \% \\
(161 \text { of } 262)\end{array}$ & $\begin{array}{l}65.2 \% \\
(150 \text { of } 230)\end{array}$ & 0.308 \\
\hline Presence of HSV-2 antibody & $\begin{array}{l}21.1 \% \\
(27 \text { of } 128)\end{array}$ & $\begin{array}{l}14.5 \% \\
(35 \text { of } 242)\end{array}$ & $\begin{array}{l}14.9 \% \\
(24 \text { of } 161)\end{array}$ & $\begin{array}{l}19.3 \% \\
(29 \text { of } 150)\end{array}$ & 0.294 \\
\hline \multicolumn{6}{|c|}{ Panel B: STD clinic Sample } \\
\hline Ever had sexual intercourse & $\begin{array}{l}93.5 \\
(43 \text { of } 46)\end{array}$ & $\begin{array}{l}94.9 \% \\
\text { (93 of } 98)\end{array}$ & $\begin{array}{l}95.8 \% \\
(68 \text { of } 71)\end{array}$ & $\begin{array}{l}96.9 \% \\
(63 \text { of } 65)\end{array}$ & 0.849 \\
\hline $\begin{array}{l}\text { Ever had gonorrhea and/or } \\
\text { chlamydia }\end{array}$ & $\begin{array}{l}32.6 \% \\
(15 \text { of } 46)\end{array}$ & $\begin{array}{l}31.3 \% \\
\text { (31 of } 99)\end{array}$ & $\begin{array}{l}33.3 \% \\
(23 \text { of } 69)\end{array}$ & $\begin{array}{l}47.0 \% \\
(31 \text { of } 66)\end{array}$ & 0.184 \\
\hline $\begin{array}{l}\text { Had sexual intercourse before } \\
\quad \text { age } 16\end{array}$ & $\begin{array}{l}45.7 \% \\
(21 \text { of } 46)\end{array}$ & $\begin{array}{l}40.8 \% \\
(40 \text { of } 98)\end{array}$ & $\begin{array}{l}45.7 \% \\
(32 \text { of } 70)\end{array}$ & $\begin{array}{l}61.5 \% \\
(40 \text { of } 65)\end{array}$ & 0.071 \\
\hline $\begin{array}{l}>1 \text { sex partner in previous six } \\
\text { months }\end{array}$ & $\begin{array}{l}50.0 \% \\
(23 \text { of } 46)\end{array}$ & $\begin{array}{l}55.1 \% \\
(54 \text { of } 98)\end{array}$ & $\begin{array}{l}41.4 \% \\
(29 \text { of } 70)\end{array}$ & $\begin{array}{l}58.5 \% \\
(38 \text { of } 65)\end{array}$ & 0.199 \\
\hline $\begin{array}{l}\text { Had at least one unprotected sex } \\
\text { act in previous six months }\end{array}$ & $\begin{array}{l}78.4 \% \\
(29 \text { of } 37)\end{array}$ & $\begin{array}{l}75.3 \% \\
(70 \text { of } 93)\end{array}$ & $\begin{array}{l}66.2 \% \\
(45 \text { of } 68)\end{array}$ & $\begin{array}{l}71.0 \% \\
(44 \text { of } 62)\end{array}$ & 0.490 \\
\hline $\begin{array}{l}\text { Is or has been pregnant, or has } \\
\text { impregnated someone }\end{array}$ & $\begin{array}{l}56.5 \% \\
(26 \text { of } 46)\end{array}$ & $\begin{array}{l}39.8 \% \\
(39 \text { of } 98)\end{array}$ & $\begin{array}{l}41.4 \% \\
(29 \text { of } 70)\end{array}$ & $\begin{array}{l}52.4 \% \\
(33 \text { of } 63)\end{array}$ & 0.158 \\
\hline Acceptance of HSV-2 test & $\begin{array}{l}100 \% \\
(46 \text { of } 46)\end{array}$ & $\begin{array}{l}94.9 \% \\
(94 \text { of } 99)\end{array}$ & $\begin{array}{l}76.1 \% \\
(54 \text { of } 71)\end{array}$ & $\begin{array}{l}91.0 \% \\
(61 \text { of } 67)\end{array}$ & $<0.001$ \\
\hline Presence of HSV-2 antibody & $\begin{array}{l}28.3 \% \\
(13 \text { of } 46)\end{array}$ & $\begin{array}{l}22.3 \% \\
(21 \text { of } 94)\end{array}$ & $\begin{array}{l}18.5 \% \\
(10 \text { of } 54)\end{array}$ & $\begin{array}{l}31.1 \% \\
(19 \text { of } 61)\end{array}$ & 0.381 \\
\hline \multicolumn{6}{|c|}{ Panel C: General Adult Clinic } \\
\hline Ever had sexual intercourse & $\begin{array}{l}91.1 \% \\
(51 \text { of } 56)\end{array}$ & $\begin{array}{l}91.9 \% \\
(57 \text { of } 62)\end{array}$ & $\begin{array}{l}95.2 \% \\
(60 \text { of } 63)\end{array}$ & $\begin{array}{l}97.3 \% \\
(72 \text { of } 74)\end{array}$ & 0.397 \\
\hline $\begin{array}{l}\text { Ever had gonorrhea and/or } \\
\text { chlamydia }\end{array}$ & $\begin{array}{l}7.0 \% \\
(4 \text { of } 57)\end{array}$ & $\begin{array}{l}20.6 \% \\
(13 \text { of } 63)\end{array}$ & $\begin{array}{l}18.3 \% \\
(11 \text { of } 60)\end{array}$ & $\begin{array}{l}24.3 \% \\
(18 \text { of } 74)\end{array}$ & 0.074 \\
\hline $\begin{array}{l}\text { Had sexual intercourse before } \\
\quad \text { age } 16\end{array}$ & $\begin{array}{l}22.8 \% \\
(13 \text { of } 57)\end{array}$ & $\begin{array}{l}43.5 \% \\
(27 \text { of } 62)\end{array}$ & $\begin{array}{l}41.3 \% \\
(26 \text { of } 63)\end{array}$ & $\begin{array}{l}47.9 \% \\
(35 \text { of } 73)\end{array}$ & 0.025 \\
\hline $\begin{array}{l}>1 \text { sex partner in previous six } \\
\text { months }\end{array}$ & $\begin{array}{l}8.9 \% \\
(5 \text { of } 56)\end{array}$ & $\begin{array}{l}9.5 \% \\
(6 \text { of } 63)\end{array}$ & $\begin{array}{l}19.0 \% \\
(12 \text { of } 63)\end{array}$ & $\begin{array}{l}14.9 \% \\
(11 \text { of } 74)\end{array}$ & 0.299 \\
\hline $\begin{array}{l}\text { Had at least one unprotected sex } \\
\text { act in previous six months }\end{array}$ & $\begin{array}{l}61.1 \% \\
(33 \text { of } 54)\end{array}$ & $\begin{array}{l}75.4 \% \\
(46 \text { of } 61)\end{array}$ & $\begin{array}{l}78.7 \% \\
(48 \text { of } 61)\end{array}$ & $\begin{array}{l}80.6 \% \\
(54 \text { of } 67)\end{array}$ & 0.072 \\
\hline
\end{tabular}


Table 4 (Continued)

\begin{tabular}{|c|c|c|c|c|c|}
\hline $\begin{array}{l}\text { Self-reported } \\
\text { behavior/outcome }\end{array}$ & $\begin{array}{l}\text { Group 1: } \\
r \leq 25 \%\end{array}$ & $\begin{array}{l}\text { Group 2: } \\
25 \%<r \leq \\
100 \%\end{array}$ & $\begin{array}{l}\text { Group 3: } \\
100 \%<r \leq \\
200 \%\end{array}$ & $\begin{array}{l}\text { Group 4: } \\
r> \\
200 \%\end{array}$ & $p$-value* \\
\hline $\begin{array}{l}\text { Is or has been pregnant, or has } \\
\text { impregnated someone }\end{array}$ & $\begin{array}{l}50.9 \% \\
(29 \text { of } 57)\end{array}$ & $\begin{array}{l}51.6 \% \\
(33 \text { of } 64)\end{array}$ & $\begin{array}{l}70.5 \% \\
(43 \text { of } 61)\end{array}$ & $\begin{array}{l}74.7 \% \\
(56 \text { of } 75)\end{array}$ & 0.005 \\
\hline Acceptance of HSV-2 test & $\begin{array}{l}43.9 \% \\
(25 \text { of } 57)\end{array}$ & $\begin{array}{l}37.5 \% \\
(24 \text { of } 64)\end{array}$ & $\begin{array}{l}47.6 \% \\
(30 \text { of } 63)\end{array}$ & $\begin{array}{l}52.0 \% \\
(39 \text { of } 75)\end{array}$ & 0.376 \\
\hline Presence of HSV-2 antibody & $\begin{array}{l}32.0 \% \\
(8 \text { of } 25)\end{array}$ & $\begin{array}{l}12.5 \% \\
(3 \text { of } 24)\end{array}$ & $\begin{array}{l}20.0 \% \\
(6 \text { of } 30)\end{array}$ & $\begin{array}{l}23.1 \% \\
(9 \text { of } 39)\end{array}$ & 0.422 \\
\hline \multicolumn{6}{|c|}{ Panel D: University campus sample } \\
\hline Ever had sexual intercourse & $\begin{array}{l}74.7 \% \\
(59 \text { of } 79)\end{array}$ & $\begin{array}{l}89.5 \% \\
(128 \text { of } 143)\end{array}$ & $\begin{array}{l}89.8 \% \\
(53 \text { of } 59)\end{array}$ & $\begin{array}{l}89.7 \% \\
(26 \text { of } 29)\end{array}$ & 0.013 \\
\hline $\begin{array}{l}\text { Ever had gonorrhea and/or } \\
\text { chlamydia }\end{array}$ & $\begin{array}{l}5.1 \% \\
(4 \text { of } 79)\end{array}$ & $\begin{array}{l}3.5 \% \\
(5 \text { of } 141)\end{array}$ & $\begin{array}{l}5.1 \% \\
(3 \text { of } 59)\end{array}$ & $\begin{array}{l}6.9 \% \\
(2 \text { of } 29)\end{array}$ & 0.854 \\
\hline $\begin{array}{l}\text { Had sexual intercourse before } \\
\text { age } 16\end{array}$ & $\begin{array}{l}11.4 \% \\
(9 \text { of } 79)\end{array}$ & $\begin{array}{l}17.5 \% \\
(25 \text { of } 143)\end{array}$ & $\begin{array}{l}22.0 \% \\
(13 \text { of } 59)\end{array}$ & $\begin{array}{l}17.9 \% \\
(5 \text { of } 28)\end{array}$ & 0.411 \\
\hline $\begin{array}{l}>1 \text { sex partner in previous six } \\
\text { months }\end{array}$ & $\begin{array}{l}9.1 \% \\
(7 \text { of } 77)\end{array}$ & $\begin{array}{l}15.1 \% \\
(21 \text { of } 139)\end{array}$ & $\begin{array}{l}27.1 \% \\
(16 \text { of } 59)\end{array}$ & $\begin{array}{l}17.9 \% \\
(5 \text { of } 28)\end{array}$ & 0.041 \\
\hline $\begin{array}{l}\text { Had at least one unprotected sex } \\
\text { act in previous six months }\end{array}$ & $\begin{array}{l}53.2 \% \\
(41 \text { of } 77)\end{array}$ & $\begin{array}{l}58.3 \% \\
(81 \text { of } 139)\end{array}$ & $\begin{array}{l}47.5 \% \\
(28 \text { of } 59)\end{array}$ & $\begin{array}{l}62.1 \%(18 \text { of } \\
29)\end{array}$ & 0.452 \\
\hline $\begin{array}{l}\text { Is or has been pregnant, or has } \\
\text { impregnated someone }\end{array}$ & $\begin{array}{l}9.2 \% \\
(7 \text { of } 76)\end{array}$ & $\begin{array}{l}7.7 \% \\
(11 \text { of } 143)\end{array}$ & $\begin{array}{l}16.9 \% \\
(10 \text { of } 59)\end{array}$ & $\begin{array}{l}17.2 \% \\
(5 \text { of } 29)\end{array}$ & 0.157 \\
\hline Acceptance of HSV-2 test & $\begin{array}{l}62.0 \% \\
(49 \text { of } 79)\end{array}$ & $\begin{array}{l}69.2 \% \\
(99 \text { of } 143)\end{array}$ & $\begin{array}{l}71.2 \% \\
(42 \text { of } 59)\end{array}$ & $\begin{array}{l}51.7 \% \\
(15 \text { of } 29)\end{array}$ & 0.206 \\
\hline Presence of HSV-2 antibody & $\begin{array}{l}10.2 \% \\
(5 \text { of } 49)\end{array}$ & $\begin{array}{l}6.1 \% \\
(6 \text { of } 99)\end{array}$ & $\begin{array}{l}14.3 \% \\
(6 \text { of } 42)\end{array}$ & $\begin{array}{l}0.0 \% \\
(0 \text { of } 15)\end{array}$ & 0.238 \\
\hline \multicolumn{6}{|c|}{ Panel E: Urban adolescent health clinic sample } \\
\hline Ever had sexual intercourse & $\begin{array}{l}75.0 \% \\
(12 \text { of } 16)\end{array}$ & $\begin{array}{l}82.6 \% \\
(38 \text { of } 46)\end{array}$ & $\begin{array}{l}84.1 \% \\
(58 \text { of } 69)\end{array}$ & $\begin{array}{l}89.7 \% \\
(52 \text { of } 58)\end{array}$ & 0.488 \\
\hline $\begin{array}{l}\text { Ever had gonorrhea and/or } \\
\text { chlamydia }\end{array}$ & $\begin{array}{l}33.3 \% \\
(5 \text { of } 15)\end{array}$ & $\begin{array}{l}28.3 \% \\
(13 \text { of } 46)\end{array}$ & $\begin{array}{l}13.0 \%(9 \text { of } \\
69)\end{array}$ & $\begin{array}{l}25.9 \% \\
(15 \text { of } 58)\end{array}$ & 0.120 \\
\hline $\begin{array}{l}\text { Had sexual intercourse before } \\
\text { age } 16\end{array}$ & $\begin{array}{l}43.8 \% \\
(7 \text { of } 16)\end{array}$ & $\begin{array}{l}63.0 \% \\
(29 \text { of } 46)\end{array}$ & $\begin{array}{l}59.7 \% \\
(40 \text { of } 67)\end{array}$ & $\begin{array}{l}70.2 \% \\
(40 \text { of } 57)\end{array}$ & 0.256 \\
\hline $\begin{array}{l}>1 \text { sex partner in previous six } \\
\text { months }\end{array}$ & $\begin{array}{l}26.7 \% \\
(4 \text { of } 15)\end{array}$ & $\begin{array}{l}26.7 \% \\
(12 \text { of } 45)\end{array}$ & $\begin{array}{l}32.4 \% \\
(22 \text { of } 68)\end{array}$ & $\begin{array}{l}35.7 \% \\
(20 \text { of } 56)\end{array}$ & 0.769 \\
\hline $\begin{array}{l}\text { Had at least one unprotected sex } \\
\text { act in previous six months }\end{array}$ & $\begin{array}{l}46.7 \% \\
(7 \text { of } 15)\end{array}$ & $\begin{array}{l}40.9 \% \\
(18 \text { of } 44)\end{array}$ & $\begin{array}{l}33.3 \% \\
(20 \text { of } 60)\end{array}$ & $\begin{array}{l}45.5 \% \\
(25 \text { of } 55)\end{array}$ & 0.556 \\
\hline $\begin{array}{l}\text { Is or has been pregnant, or has } \\
\text { impregnated someone }\end{array}$ & $\begin{array}{l}33.3 \% \\
(5 \text { of } 15)\end{array}$ & $\begin{array}{l}30.4 \% \\
(14 \text { of } 46)\end{array}$ & $\begin{array}{l}30.3 \% \\
(20 \text { of } 66)\end{array}$ & $\begin{array}{l}28.6 \% \\
(16 \text { of } 56)\end{array}$ & 0.987 \\
\hline Acceptance of HSV-2 test & $\begin{array}{l}50.0 \% \\
(8 \text { of } 16)\end{array}$ & $\begin{array}{l}54.3 \% \\
(25 \text { of } 46)\end{array}$ & $\begin{array}{l}50.7 \% \\
(35 \text { of } 69)\end{array}$ & $\begin{array}{l}59.3 \% \\
(35 \text { of } 59)\end{array}$ & 0.784 \\
\hline Presence of HSV-2 antibody & $\begin{array}{l}12.5 \% \\
(1 \text { of } 8)\end{array}$ & $\begin{array}{l}20.0 \% \\
(5 \text { of } 25)\end{array}$ & $\begin{array}{l}5.7 \% \\
(2 \text { of } 35)\end{array}$ & $\begin{array}{l}2.9 \% \\
(1 \text { of } 35)\end{array}$ & 0.110 \\
\hline
\end{tabular}

\footnotetext{
*The $p$-values (Pearson's chi-square) test the null hypothesis that there is no association between the self-
} reported behavior/outcome and the columns (discount rates). 
no risk of STD acquisition for a person in a mutually monogamous relationship with an uninfected partner, and unprotected sex within monogamous relationships may be the reason why unprotected sex was more common in the general adult medical clinic sample than in any other site, including the STD clinic. Furthermore, condom usage can vary substantially within subjects over time. For example, youth who report consistent condom usage over a given three-month period might report inconsistent or no condom usage over a subsequent three-month period (Peterman et al., 2006).

The results were similar when we stratified the respondents by sex (not shown). Females with higher discount rates were more likely to ever had gonorrhea or chlamydia, to have had sexual intercourse before age 16 years, and to have been or currently be pregnant. However, for females, the association between discount rates and (1) ever having sex and (2) having more than one sex partner in the previous six months were no longer significant at the $p<0.05$ level. Males with higher discount rates were more likely to have ever had sexual intercourse, to have ever had gonorrhea or chlamydia, to have had sexual intercourse before age 16 years, and to have had more than one sex partner in the previous six months. For males, the association between discount rates and pregnancy status (which for males indicates ever having impregnated someone) was not significant at the $p<0.05$ level.

The associations between discount rates and sexual behaviors were more evident for the general medical clinic sample and the university campus sample than for the STD clinic sample and the adolescent health clinic sample. For the STD clinic sample, those in higher discount rate groups were more likely to have had sexual intercourse before age 16 and were less likely to accept HSV-2 antibody testing (Table 4, Panel B). For the general adult medical clinic sample, those in higher discount rate groups were more likely to report ever having gonorrhea or chlamydia, having sexual intercourse before age 16, having at least one unprotected sex act in the previous six months, and having been pregnant or impregnating someone (Table 4, Panel C). In the university campus sample, higher discount rates were associated with ever having sexual intercourse and with having more than one sex partner in the previous six months (Table 4, Panel D). In the teen clinic sample, there were no associations (at the $p<0.10$ level) between discount rate group and sexual behaviors (Table 4, Panel E).

For the full sample, the associations between discount rates and sexual behaviors and health outcomes were similar when we performed ordinal logistic regression to control for differences in age, sex, race, and site of data collection. We performed eight regressions, each time including one of the sexual behavior/outcome variables as a dependent variable. The independent variable of interest was the discount rate group, and each regression also included age, sex, race and recruitment site variables. ${ }^{10}$ Higher discount rates were associated with ever having sexual intercourse, ever having gonorrhea or chlamydia, having sexual intercourse before the age of 16 years, and past or current pregnancy (or impregnating someone) (Table 5). ${ }^{11}$

To examine what demographic factors influenced the discount rates, we reversed our model and included the discount rate group as the dependent variable and included as independent variables the demographic and site variables and all of the sexual behavioral and

\footnotetext{
10 The variable AGE was continuous, and the variables MALE and WHITE were dummy variables set to 1 for male and white respondents, respectively. The site variables were dummy variables for general medical clinic, university, and teen clinic (STD clinic was the omitted site variable).

11 The association between discount rates and having sex before age 16 held when we deleted observations from the small portion of the sample who were under the age of 16. Similarly, deleting observations from respondents without sexual experience (and omitting the "ever having sex" variable) had no substantial impact on the results for the other sexual behavior variables.
} 
Table 5 Ordinal logistic regression models: Associations between discount rates and sexual behaviors and health outcomes

\begin{tabular}{lrr}
\hline & $\begin{array}{l}\text { Estimate of discount } \\
\text { rate coefficient (SE) }\end{array}$ & $p$-value \\
\hline Ever had sexual intercourse & $0.431(0.126)$ & $<0.001$ \\
Ever had gonorrhea and/or chlamydia & $0.167(0.089)$ & 0.062 \\
Had sexual intercourse before age 16 & $0.230(0.071)$ & 0.001 \\
$>$ 1 sex partner in previous six months & $0.107(0.080)$ & 0.183 \\
Had at least one unprotected sex act in previous six months & $0.076(0.073)$ & 0.298 \\
Is or has been pregnant, or has impregnated someone & $0.152(0.076)$ & 0.045 \\
Acceptance of HSV-2 test & $0.022(0.074)$ & 0.769 \\
Presence of HSV-2 antibody & $-0.051(0.111)$ & 0.645 \\
\hline
\end{tabular}

This table summarizes the results of eight regressions, each of which included one of the behavioral or outcome variables as the dependent variable. In each regression, we included the discount rate group, AGE, MALE, WHITE, and site variables (general medical clinic, university, teen clinic, STD clinic) as independent variables. Coefficients for AGE, MALE, WHITE, and site variables are not reported but are available from the authors upon request. All behavioral/outcome variables were self-reported except HSV-2 antibody test. Positive coefficients indicate that those in higher discount rate groups were more likely to report the sexual behavior or health outcome.

health outcome variables (except HSV-2 antibody status, which was not available for the full sample). Older respondents and white respondents were more likely to belong to lower discount rate groups (Table 6). Ever having sex, having sex before age 16, and pregnancy status were associated with higher discount rates.

\subsection{Additional analyses: Testing the validity of the discount rate measurement}

As noted earlier, our measure of discount rates is based on responses to three questions and is better suited for assessing relative differences in time preference rather than absolute rates of time preference. Furthermore, our relative ranking of discount rate groups might reflect the

Table 6 Ordinal logistic regression model: Predictors of higher discount rates

\begin{tabular}{lrr}
\hline Variable & Estimate (SE) & $p$ value \\
\hline Age & $-0.084(0.021)$ & $<0.001$ \\
Male & $0.119(0.132)$ & 0.368 \\
White & $-0.428(0.155)$ & 0.006 \\
General medical clinic site & $0.075(0.199)$ & 0.707 \\
University site & $-0.546(0.178)$ & 0.002 \\
Teen clinic site & $-0.010(0.231)$ & 0.966 \\
Ever had sexual intercourse & $0.696(0.249)$ & 0.005 \\
Ever had gonorrhea, chlamydia, or both & $0.117(0.178)$ & 0.512 \\
Had sexual intercourse before age 16 years & $0.288(0.146)$ & 0.049 \\
Had more than one sex partner in previous six months & $0.111(0.152)$ & 0.466 \\
Had at least one unprotected sex act in previous six months & $-0.128(0.139)$ & 0.359 \\
Is or has been pregnant, or has impregnated someone & $0.248(0.151)$ & 0.100 \\
Acceptance of HSV-2 test & $-0.072(0.145)$ & 0.618 \\
\hline
\end{tabular}

Note. Overall model was significant (chi-square $=124.7, p<0.001$ ). Positive coefficients indicate a higher probability of having a higher discount rate. 
influence of other factors besides time preferences (such as "anchoring" to the first monetary tradeoff, or beliefs about inflation or future consumption, as described by Frederick et al. (2002)) or survey response biases (such as a tendency to respond with "agree" rather than "disagree," as reviewed by Krosnick (1999)). Although we cannot rule out the possibility of such biases, we can examine the reliability of our results over a range of additional analyses.

First, to account for the potential bias due to anchoring to the first monetary question, and to examine the robustness of our findings to inclusion of inconsistent respondents, we performed additional analyses in which we measured relative differences in discount rates based only on the responses to the first question (without deleting observations due to inconsistent responses to the second and third questions). ${ }^{12}$ We obtained similar results, except that the associations between relative discount rates and ever having sex and having more than one recent sex partner were not as strong.

Second, to address the possible bias of acquiescence, we repeated the analysis after excluding all subjects who responded "strongly agree" or "agree" to all three monetary questions. Such patterns of agreement might reflect the passive responses of subjects who did not understand the survey or did not want to exert effort in responding to the survey (Krosnick, 1999). When such responses were excluded, we still detected significant associations between relative discount rates and several sexual behaviors, although these associations were not as strong as when all responses were included. ${ }^{13}$

Third, and perhaps most importantly, we note that the associations we observed between relative discount rate groups and demographic variables (Table 6) were consistent with findings from previous studies. For example, we found that discount rates decreased with age, as has been reported in numerous previous studies. ${ }^{14}$ Furthermore, respondents from the university setting had lower discount rates, consistent with previous studies showing a link between discount rates and the decision to seek higher education. ${ }^{15}$ We also found that being white was a predictor of lower discount rates, consistent with previous reports. ${ }^{16}$ However, this finding might be attributable to differences in income, as higher incomes are also predictors of lower discount rates (see Lawrance, 1991). Regardless, the fact that the correlations we observed between relative discount rates and demographic factors were consistent with previous research adds to the credibility of our assessment of relative discount rates.

\section{Conclusions}

We found high discount rates in a sample of teenagers and young adults. Higher discount rates were significantly associated with a range of risky sexual behaviors and health outcomes, including having sex before age 16 , having gonorrhea or chlamydia, and pregnancy

\footnotetext{
${ }^{12}$ We classified the participants into five groups, based on their responses to the first monetary payoff question. The possible responses ranged from 1 (strongly disagree) to 5 (strongly agree), with 5 being the highest relative discount rate. The distribution of the responses was $38 \%$ (strongly disagree), $25 \%, 9 \%, 16 \%$, and $11 \%$ (strongly agree).

${ }^{13}$ Specifically, discount rates were associated (at the $p<0.05$ level) with ever having sex, having sex before age 16 , having more than one sex partner in the previous six months, and pregnancy status, although only the first two associations were significant at the $p<0.05$ level in the logistic regression models which controlled for age, sex, race, and recruitment site.

${ }^{14}$ For example, see Green et al. (1996), Green et al. (1999), Warner and Pleeter (2001), Read and Read (2004), and Bishai (2004).

${ }^{15}$ Examples include Viscusi and Moore (1989), Warner and Pleeter (2001), and Bishai (2004).

${ }^{16}$ For example, see Lawrance (1991), Warner and Pleeter (2001) and Bishai (2004).
} 
status. Although our findings were robust to alternative analyses designed to address potential shortcomings in our assessment of individual discount rates, our analysis is exploratory in nature, and future research is needed to examine the association between time preference and sexual behaviors in more detail.

If time preference does in fact influence sexual behavioral decision making, the implications could be important. First, the associations we found between sexual behaviors and discount rates suggest that sexual behavior data can potentially be used in studies that require measures correlated with time preference. For example, smoking status and educational attainment are both affected by discount rates, and researchers have used smoking status as an instrument for education in estimating the link between educational attainment and earnings (Evans and Montgomery, 1994; Fersterer and Winter-Ebmer, 2003). Perhaps sexual behavioral data could be adapted for similar purposes in the future.

Second, our findings offer empirical support for the idea that the short-term decisionmaking focus of teenagers and young adults may be a key factor in the decision to engage in risky sex. Youth may make behavioral choices that they regret later, because they discount the future "too much" or because they fail to realize their preferences might change over time. ${ }^{17}$ Thus, as noted by O'Donoghue and Rabin (2001), teenagers and young adults, even if fully aware of the potential consequences of various sexual behaviors, might make choices that adversely affect their health because they greatly discount these future consequences. Furthermore, these results support the recommendation of the Centers for Disease Control and Prevention (2002) that STD prevention messages should highlight the potential shortterm consequences of STDs, which might be of more importance to teenagers and young adults than potential long-term consequences.

Acknowledgment The findings and conclusions in this report are those of the authors and do not necessarily represent the views of the Centers for Disease Control and Prevention. This work was supported in part by a cooperative agreement from the Centers for Disease Control and Prevention (\#UR6/CCU517826). The authors would like to thank the CDC project officer Katherine M. Stone, M.D., for her guidance, and Kathleen Irwin, M.D., and two anonymous reviewers for helpful comments and suggestions.

\section{References}

Bishai, David M. (2004). “Does Time Preference Change with Age?” Journal of Population Economics 17 , 583-602.

Bishai, David M., Dan Mercer, and Athena Tapales. (2005). "Can Government Policies Help Adolescents Avoid Risky Behavior?” Preventive Medicine 40, 197-202.

Centers for Disease Control and Prevention. (2002). Program Operations Guidelines for STD Prevention: Community and Individual Behavior Change Interventions. Atlanta, GA: Centers for Disease Control and Prevention.

Chaloupka, Frank. (1991). "Rational Addictive Behavior and Cigarette-Smoking," Journal of Political Economy $99,722-742$.

Chapman, Gretchen B. and Elliot J. Coups. (1999). "Time Preferences and Preventive Health Behavior: Acceptance of the Influenza Vaccine," Medical Decision Making 19, 307-314.

Chapman, Gretchen B. and Arthur S. Elstein. (1995). "Valuing the Future: Temporal Discounting of Health and Money," Medical Decision Making 15, 373-386.

Chapman, Gretchen B. (2002). "Your Money or Your Health: Time Preference and Trading Money for Health," Medical Decision Making 22, 410-416.

\footnotetext{
17 This could apply to decisions about sexual behaviors and other choices faced by teenagers and young adults. For examples, see Leibowitz et al. (1986), Chaloupka (1991), Chapman and Elstein (1995), Laux (2000), Levine (2001), Gruber (2001), O’Donoghue and Rabin (2001), Grossman et al. (2002), and Bishai, Mercer, and Tapales (2005).
} 
Chapman, Gretchen B. (2005). "Short-Term Cost for Long-Term Benefit: Time Preference and Cancer Control," Health Psychology 24, S41-S48.

Chesson, Harrell and W. Kip Viscusi. (2000). "The Heterogeneity of Time-Risk Tradeoffs," Journal of Behavioral Decision Making 13, 251-258.

Chesson, Harrell W. et al. (2004). "The Estimated Direct Medical Cost of Sexually Transmitted Diseases Among American Youth, 2000," Perspectives on Sexual and Reproductive Health 36(1), 11-19.

Evans, William N. and Edward Montgomery. (1994). "Education and Health: Where there's Smoke there's an Instrument," National Bureau of Economic Research Working Paper Series, Working Paper 4949.

Fersterer, Josef and Rudolf Winter-Ebmer. (2003). "Smoking, Discount Rates, and Returns to Education," Economics of Education Review 22, 561-566.

Fife, Kenneth H. et al. (2004). "Predictors of Herpes Simplex Virus Type 2 Antibody Positivity Among Persons with no History of Genital Herpes," Sexually Transmitted Diseases 31(11), 676-681.

Fortenberry, J. Dennis et al. (2004). "Return for Results After Herpes Simplex Virus Type 2 Screening," Sexually Transmitted Diseases 31(11), 655-658.

Frederick, Shane, George Loewenstein and Ted O'Donoghue. (2002). “Time Discounting and Time Preference: A Critical Review," Journal of Economic Literature 40, 351-401.

Fuchs, Victor R. (1982). “Time Preference and Health: An Exploratory Study,” In: Victor R. Fuchs (ed.), Economic Aspects of Health. Chicago: University of Chicago Press, pp. 93-120.

Green, Donald et al. (1998). "Referendum Contingent Valuation, Anchoring, and Willingness to Pay for Public Goods," Resource and Energy Economics 20, 85-116.

Green, Leonard et al. (1996). "Temporal Discounting in Choice Between Delayed Rewards: The Role of Age and Income," Psychology and Aging 11, 79-84.

Green, Leonard, Joel Myerson and Pawel Ostaszewski. (1999). "Discounting of Delayed Rewards Across the Life Span: Age Differences in Individual Discounting Functions," Behavioural Processes 46, 89-96.

Grossman, Michael, Frank J. Chaloupka and Kyumin Shim. (2002). "Illegal Drug use and Public Policy," Health Affairs 21, 134-145.

Gruber, Jonathon. (2001). "Introduction,” In: Jonathon Gruber (ed.), Risky Behavior among Youths: An Economic Analysis. Chicago: University of Chicago Press.

Kirby, Kris N. and Nancy M. Petry. (2004). "Heroin and Cocaine Abusers have Higher Discount Rates for Delayed Rewards than Alcoholics or Non-Drug-Using Controls," Addiction 99, 461-471.

Komlos, John, Patricia K. Smith and Barry Bogin. (2004). "Obesity and the Rate of Time Preference: Is there a Connection?” Journal of Biosocial Science 36, 209-219.

Krosnick, Jon A. (1999). “Survey Research,” Annual Review of Psychology 50, 537-567.

Laux, Fritz L. (2000). "Addiction as a Market Failure: Using Rational Addiction Results to Justify Tobacco Regulation," Journal of Health Economics 19, 421-437.

Lawrance, Emily C. (1991). "Poverty and the Rate of Time Preference: Evidence from Panel Data," Journal of Political Economy 99, 54-77.

Leibowitz, Arleen, Marvin Eisen and Winston K. Chow. (1986). "An Economic Model of Teenage Pregnancy Decision-Making," Demography 23, 67-77.

Levine, Phillip B. (2001). "The Sexual Activity and Birth-Control Use of American Teenagers,” In: Jonathon Gruber (ed.), Risky Behavior among Youths: An Economic Analysis. Chicago: University of Chicago Press, pp.167-217.

Loewenstein, George. (2005a). "Projection Bias in Medical Decision Making," Medical Decision Making 25, 96-105.

Loewenstein, George. (2005b). "Hot-Cold Empathy Gaps and Medical Decision Making," Health Psychology 24, S49-S46.

Munasinghe, Lalith and Nachum Sicherman. (2000). "Why do Dancers Smoke? Time Preference, Occupational Choice, and Wage Growth,” National Bureau of Economic Research Working Paper Series, Working Paper 7542 .

O’Donoghue, Ted and Matthew Rabin. (2001). "Risky Behavior Among Youth: Some Issues from Behavioral Economics,” In: Jonathon Gruber (ed.), Risky Behavior among Youths: An Economic Analysis. Chicago: University of Chicago Press, pp. 29-67.

Peterman, Thomas A. et al. (2000). "Does Measured Behavior Reflect STD Risk?: An Analysis of Data from a Randomized Controlled Behavioral Intervention Study," Sexually Transmitted Diseases 27, 446-451.

Peterman, Thomas A. et al. (2006). "Who Uses Condoms After an STD Clinic Visit, and Why?" National STD Prevention Conference, Abstract 355. Jacksonville, Florida, May 8-11, 2006.

Phelps, E. S. and R. A. Pollak. (1968). "On Second-Best National Saving and Game-Equilibrium Growth," Review of Economic Studies 35, 185-199.

Picone, Gabriel, Frank Sloan and Donald Taylor. (2004). "Effects of Risk and Time Preference and Expected Longevity on Demand for Medical Tests," Journal of Risk and Uncertainty 28, 39-53. 
Read, Daniel. (2001a). "Is Time-Discounting Hyperbolic or Subadditive?" Journal of Risk and Uncertainty 23, 5-32.

Read, Daniel. (2001b). "Intrapersonal Dilemmas," Human Relations 54, 1093-1117.

Read, Daniel and Peter Roelofsma. (1999). "Hard Choices and Weak Wills: the Theory of Intrapersonal Dilemmas," Philosophical Psychology 12, 341-356.

Read, Daniel and Peter H. M. P. Roelofsma. (2003). "Subadditive Versus Hyperbolic Discounting: A Comparison of Choice and Matching" Organizational Behavior and Human Decision Processes 91, 140-153.

Read, Daniel and N. L. Read. (2004). "Time Discounting Over the Life Span" Organizational Behavior and Human Decision Processes 94, 22-32.

Upchurch, Dawn M. et al. (2004). "Social and Behavioral Determinants of Self-Reported STD Among Adolescents," Perspectives on Sexual and Reproductive Health 36, 276-287.

Viscusi, W. Kip. (1991). "Age Variations in Risk Perceptions and Smoking Decisions," Review of Economics and Statistics 73, 577-588.

Viscusi, W. Kip and Joni Hersch. (2001). "Cigarette Smokers as Job Risk Takers," Review of Economics and Statistics 83, 269-280.

Viscusi, W. Kip, Wesley A. Magat and Joel Huber. (1991). "Pricing Environmental-Health Risks: Survey Assessments of Risk-Risk and Risk-Dollar Trade-Offs for Chronic-Bronchitis" Journal of Environmental Economics and Management 21, 32-51.

Viscusi, W. Kip and Michael J. Moore. (1989). "Rates of Time Preference and Valuations of the Duration of Life," Journal of Public Economics 38, 297-317.

Warner, John T. and Saul Pleeter. (2001). "The Personal Discount Rate: Evidence from Military Downsizing Programs," American Economic Review 91, 33-53.

Weinstock, Hillard, Stuart Berman and Willard Cates, Jr. (2004). "Sexually Transmitted Diseases Among American Youth: Incidence and Prevalence Estimates, 2000," Perspectives on Sexual and Reproductive Health 36(1), 6-10.

Zimet, Gregory D. et al. (2004). "Factors Predicting the Acceptance of Herpes Simplex Virus Type 2 Antibody Testing Among Adolescents and Young Adults," Sexually Transmitted Diseases 31, 665-669. 